\title{
Research on Interactive and Exploratory Teaching Methods used in College English Courses
}

\author{
Yingxin Zhang* \\ Department of Foreign Languages, Harbin Engineering University, Heilongjiang Province, China \\ Funding: \\ Heilongjiang Province Economic and Social Development Key Research Project: Research on the Theory and Practice of \\ Foreign Language Education in Heilongjiang Colleges and Universities from a Cross-cultural Perspective (WY2019037- \\ B). \\ The 2019 Harbin Engineering University undergraduate teaching reform research project research-based teaching and \\ process assessment special project "Analysis and Research on Learning Motivation and Strategies of Ethnic Minority \\ Undergraduates in Local Universities under the Background of Double First-class" (JG2019B87).

\begin{abstract}
This research is based on the implementation of interactive and exploratory teaching methods in college English courses. The analysis done for this research signifies the importance of interactive-exploratory teaching methods, identifying the characteristics of interactive teaching methods, and specifying the purpose of conducting interactive-exploratory teaching methods as a reference for educators.
\end{abstract}

Keywords: College English courses; Interactive-exploratory teaching methods; Implementation method

Publication date: May, 2021; Publication online: 31 May, 2021

*Corresponding author: Yingxin Zhang, 250439990@ qq.com

\section{Introduction}

As one of the basic courses in colleges and universities, English is pertinent, functional, and humanistic. While teaching students to learn language skills, educators must include the importance of humanistic education. This will allow the students to understand moral values, cultural characteristics and ideas while learning the syllabus, thereby establishing an overall achievement.

\section{Importance of Interactive and Exploratory Teaching Methods in College English Courses}

\subsection{Improving teaching methods}

To avoid problems of dependent learning in college English courses, lecturers would guide students to learn independently. Although this teaching method is still in progress, in the long run, it may increase the students' interest in learning. In the process of learning English, students will not be able to experience in-depth learning due to the lack of learning facilities, thus, leading to serious polarization problems. ${ }^{[1]}$ Hence, it is necessary for lecturers to change their concept of teaching and adopt a variety of teaching methods to improve the students' English skills. College level education is different from other levels of education whereby, college level English courses usually prioritizes the importance of student's ability to apply the English language. Hence, lecturers need to encourage students to develop their oral skills. Lecturers may also use multi-dimensional interactive modules to conduct interactive teaching methods, discuss activities with their students and spend more time to help them improve their language skills as a form of enhancement to their teaching methods. 


\subsection{Promoting students' interest in learning}

It is necessary for students to have an interest in learning at each level of education. It is prioritized and repeatedly emphasized by the Ministry of Education to improve students' interest in learning. ${ }^{[2]}$ However, college students have very little interest in learning English. This is because many lecturers only pay attention to whether students have gained enough knowledge during classes but ignore the issue of whether students are able to apply that knowledge. This negligence leads to students being hardly able to converse in English, to the extent that the students are not interested in learning English anymore. Therefore, lecturers should integrate relevant activities and multidimensional interactive methods into the teaching process, in order to cultivate students' interest in learning as well as to improve interaction with students. For example, organizing activities such as English drama performances or English film dubbing may help students gain the ability to use English proficiently through an educational way. The attractive activities conducted in English will help to improve students' comprehensive and understanding skills. ${ }^{[3]}$

\subsection{Improving teaching efficiency}

Due to issues with the teaching methods in English courses, it may lead to inefficient teaching; thereby affecting the students' ability to learn. Hence, lecturers should adopt suitable teaching methods to guide students to avoid those problems. Multidimensional interaction is an effective way to improve teaching efficiency, in-depth learning, and students' appreciation for the classroom environment. This provides an opportunity for teachers to communicate with students in order to understand the course-based problems the students are facing and to avoid students from being overly dormant during their English classes. ${ }^{[4]}$ Moreover, by organizing suitable educational activities for students, they will be able to thoroughly understand the course content in the learning process. Improvements via these methods would increase the efficiency of lecturers, thereby allowing students to learn independently.

\section{Characteristics of Interactive and Exploratory Teaching Methods used in College English Courses}

\subsection{Multi-dimensional nature of interactive strategies}

Compared to previous teaching methods, there are many strategies in the interactive method which can effectively improve students' comprehensive abilities and promote overall development. In the traditional teaching method, lecturers focus on practicality by requiring most students to memorize theoretical knowledge while neglecting students' interest; thus, failing to fully realize the importance of their intellectual needs. Although, theoretical performance and practical skills would improve significantly, it cannot meet their intellectual needs. Therefore, the interactive method emphasizes on the multi-dimensional nature of interactive strategies, which meets the intellectual needs of students. This would also require close communication as well as cooperation between interactive objects to improve the effectiveness of classroom teaching. ${ }^{[5]}$

\subsection{Utilizing various interactive objects}

After a period of using interactive methods in teaching, lecturers realized the role of students in the curriculum. In regard to that, by giving them enough respect and placing importance on student' feedbacks may help in the improvement of these teaching methods. Hence, the teaching standards of lecturers will be greatly improved. On the other hand, during the time when traditional teaching methods were used, the interaction between students have not been emphasized. Communication between students were less, hence, it was difficult to discover problems faced by students. Eventually, students were not able to learn effectively. Traditional teaching methods have negative impacts on teaching results. In the case of using interactive methods, it does not only require good communication between lectures and students 
but also, communication and connection-building among students. Students will also learn relevant knowledge through communication with their teachers and friends. This kind of communication will stimulate the classroom environment as well as to ensure orderly and an effective learning curve. ${ }^{[6]}$

\subsection{Dynamic interactive method}

The dynamic nature of interaction is a common feature of interactive methods. It encourages lecturers to recognize the limitations of the curriculum and provides a reliable foundation for the lecturers in order to improve. This ensures the development of effective and orderly teaching methods as well as to achieve teaching goals. In actual classrooms, lecturers must comprehensively and meticulously evaluate the students learning ability, teaching content, etc., and determine the implementation plan of the interactive method to ensure its effectiveness for the students. In addition, lecturers should pay attention to the transition from non-verbal to verbal behaviors so that the interactive methods of educational activities will leave positive impacts on students. Teachers can also switch flexibly between the discussion-based method as well as the question-and-answer method to improve the teaching efficiency. ${ }^{[7]}$

\subsection{Lecturers and students regarded as equals in the interactive method}

A typical feature of the interactive method is that both parties provide equal interaction. The interactive method is different from other teaching methods as it treats both, the lecturer and student as two equal individuals. It also requires interactive objects to complete educational activities through dialogues and collaborations; whereas in the traditional teaching method, teachers are the dominant figure which makes it difficult to fully reflect on the student's position. This causes a lack of interest and passivity among students during classes. As a result, the classroom environment becomes dull and unfavorable, hence, reducing the teaching efficiency. The focus of the interactive method is to establish an equal and harmonious relationship between lecturers and students. This can be achieved by eliminating the gap between lecturers and students as much as possible, thereby, meeting the intellectual needs of students, eliminating student resistance and reducing the difficulty of teaching.

\section{Application of Interactive and Explorative Teaching Methods used in College English Courses}

\subsection{Encouraging students to learn English by conducting lecturer-student interactive teaching methods}

Nowadays, English courses conducted in colleges must be improved and improvised regularly as it needs to meet the society's requirement for better teaching qualities. During classes, lecturers need to clarify their roles as well as the students'. The prioritization of students' needs provides a form of encouragement for students to be more involved in class. Hence, when students gain interest in learning English, they will be more enthusiastic and actively participate in activities during English lessons. This will create a harmonious and stable classroom environment while providing opportunities for oral practice in order to improve students' English proficiency. In classroom teaching, lecturers should be aware of their words and actions. For instance, lectures should establish equal and harmonious teacher-student relationships by treating each student equally with the same passionate attitude. This will help students feel more comfortable in their learning. In addition to that, during activities, lecturers should be responsible to provide necessary help for students in need to prevent them from falling too far behind. This allows them to build their confidence and instill a self-initiative attitude in learning English. Lecturers should be organized, provide proper instructions, and encourage students to engage in group discussions, performances, lecturer-student dialogues, mutual evaluation as well as other learning activities. This would increase students' participation in the classroom and promote learning. As a result, there will be improvement in the 
students' English proficiency and the quality of teaching English in colleges. ${ }^{[8]}$

\subsection{Encouraging group discussions during class to promote the interaction between students}

In college, by effectively interacting with each other, students can eliminate negative thoughts, behaviors, emotional barriers, and learning anxiety; hence, improving learning efficiency. In addition to that, it can also improve academic performance and promote personality development. In the use of traditional teaching methods, lecturers had a perception that students were not motivated to learn, lacked self-confidence, and avoided asking questions during class. This led to self-isolation and inferiority complex issues in students. On the contrary, the concept of interactive and exploratory teaching method focuses more on utilizing the involvement of students. Under the lecturers' supervisions, students can manage most of the classroom teachings, improve their interactions, and obtain mutual learning development. The interactive teaching method for English courses in colleges and universities adopts this innovative way of student-student interaction. It is necessary to change or improvise teaching methods while basing on contents from the textbook. In order to encourage class participation, interactive activities can be conducted such as organizing group discussions, oral or formal dialogues as well as role playing. These activities will boost the students' level of enthusiasm for learning, thus improving the efficiency in teaching English. According to textbook contents, students may select the type of interaction for the entire class while considering the lecturers' urge for interaction. For instance, lecturers can direct questions and the students actively discuss and answer the questions. Thereafter, students should analyze and evaluate their learnings from the lesson. By forming smallscale interactive groupings, students can work together through discussion or role-playing; thereby, focusing on each student's personality. This helps students to develop the skills needed for proper use of English and improve the efficiency of college English teaching method.

\subsection{Use exploratory resources to conduct activities for college English course}

Classroom teaching is a major part of learning English in college. However, to learn English more effectively, lecturers should encourage students to use their spare time to enhance the learning process. Thus, by combining their textbook knowledge, the students will be able to test themselves on their ability to apply the learnt knowledge. In regard to that, lecturers can also organize English writing competitions, dramas or musical activities to improve students understanding of standard English writing and to help students develop their English creativity as well as application skills, respectively. Additionally, this teaching method can also be used as an educational activity to create awareness and protect the environment whereby students will come up with their own slogans and mottos. With all these activities, there will be a pleasant educational environment on campus which allows students to learn, converse in English comfortably and improve their English application skills. Other than that, information technology platforms such as WeChat, QQ, DingTalk, and email can also be used to interact with students to promote the interaction between lecturers and students, motivate students to learn English, as well as to establish a harmonious relationship.

\subsection{Integrating educational resources to promote a comfortable and happy environment to learn English}

A stable and harmonious relationship with the environment is the basis for the development of multi-dimensional interaction. In this case, learning and interaction can be promoted by a comfortable and happy environment for the students. However, each student has different personalities. Hence, teachers need to respect and cater to the needs of each individual so that they will be able to achieve academic excellence accordingly, in addition to providing a comfortable environment to encourage the importance of persistent learning. The current education system still uses grades to evaluate a student's level of knowledge. Therefore, it requires 
teachers to not only pay attention to academic performances, but also to encourage students to use English during classes and in their daily lives. The lecturer should guide students to improve themselves in various ways. For example, during classes, lecturers need to help students recognize, understand the cause, and to correct their mistakes, while encouraging students to continuously strive for improvement. Thus, teachers should attempt to create an environment that encourages interactive learning, whereby students can learn in a comfortable and harmonious environment. As a result, it effectively improves the quality of teaching, enhances students' interest in learning, and effectively improves English teaching methods in college. Eventually, promoting the development of students to attain overall achievements.

\section{Summary}

In summary, the application of interactive and exploratory teaching method is very important for English courses in college. This method regards students as the priority of the classroom. It also focuses on having group discussions, integrating relevant resources and spending spare time to gain more knowledge. Understanding the effectiveness of interactive teaching by emphasizing discussions among students as well as interactions between teachers and students will improve the English teaching methods in colleges.

\section{Disclosure statement}

The author discloses no conflicts of interest.

\section{References}

[1] Li, J(2020). The Practice and Application of Multi-Dimensional Interactive Teaching Mode in College English Teaching. Overseas English, (21): 115-116.

[2] Huan, L(2020). The Application of Classroom Interactive Teaching Mode in College English Teaching. Campus English, (45): 80-81.

[3] Qian, Li(2020). The Practice and Application of Multi-Dimensional Interactive Teaching Mode in College English Teaching. Campus English, (44): 39-40.

[4]Na, Y(2020). The Application of MultiDimensional Interactive Teaching Mode in College English Teaching. Journal of Yanbian Education College, 34(05): 193-194, 198.

[5]Ning, G(2020). The Application Effect of Multi-Dimensional Interactive Teaching Mode in College English Teaching. Curriculum Education Research, (40): 63-64.

[6] Lv, L(2020). The Implementation Path of MultiDimensional Interactive Teaching Mode in College English Teaching. Campus English, (35): 30-31. [7] Yan, F(2020). The Application of Classroom Interactive Teaching Mode in College English Teaching. Literature Education (Part 1), (08): 172173.

[8] Jing, Ge(2020). The Application Research of Multi-Dimensional Interactive Teaching Mode in College English Teaching. Campus English, (34): 22-23. 